\title{
Effects of herbage allowance on performances of dairy cows grazing alfalfa swards
}

\author{
E Comerón 1, L Romero 1, JL Peyraud 2, O Bruno 1, L Delaby 2 \\ IINTA Estación Exp Agrop Rafaela, CC 22, 2300 Rafaela-Santa Fe, Argentina ; \\ 2/NRA Station de Recherches sur la Vache Laitière, 35590 St-Gilles, France
}

On perennial ryegrass sward, herbage allowance (HA) greatly affect milk production and herbage intake by grazing dairy cows (Combellas and Hodgson, 1979, Grass and Forage Sci, 34, 209-214). This trial aimed at studying the effects of HA when cows grazed pure alfalfa swards.

Three levels of daily herbage allowance : 10 (SG10), 20 (SG20) and 30 (SG30) kg $\mathrm{DM} / \mathrm{cow} / \mathrm{d}$ (herbage mass measured by motorscythe at $4 \mathrm{~cm}$ height) were compared in a $3 \times 3$ latin square design using 3 groups of 6 cows. The cows strip grazed a plot of Medicago sativa (cv Monarca INTA) at Rafaela ( $31^{\circ} 11$ 'S latitude and $61^{\circ} 33^{\prime} \mathrm{W}$ longitude). Each group consisted of 3 early lactating cows (SL1, 50 days of lactation) and 3 late lactating cows (SL2, 240 days). Each period lasted 7 days and measurements were made during the last three days. Milk production and composition were recorded. Herbage intake was estimated from sward cutting techniques. The cows did not receive supplementary feed during the trial. Data were tested using an analysis of variance with period, treatment, stage of lactation, individual cow (within stage) and interactions "stage x treatment" and "stage x period" as sources of variation.
The herbage mass on offer did not vary between period $(2.6 \mathrm{t} \mathrm{DM} / \mathrm{ha})$ but the in vitro dry matter digestibility (IVDMD) of the sward decreased from 65.4 to $60.0 \%$ from period 1 to 3. Increasing HA increased linearly milk production $(+0.25 \mathrm{~kg}$ milk $/ \mathrm{kg} \mathrm{HA})$ and decreased linearly milk fat content. Milk protein and casein contents were not changed. No interaction was found between milk production and stage of lactation. In contrast, the mean response on milk fat content was essentially due to a sharp decrease for the late lactating cows (from 45.7 to $37.8 \mathrm{~g} / \mathrm{kg}$ between SG10 and SG30). Herbage intake increased in a curvilinear manner with HA. Milk C18:1 content decreased from SG10 to SG20, the effect being more important for cows in early stage of lactation (33 to $28 \%$ vs 30 to $27 \%$ for SL1 and SL2, respectively). This may indicate a higher body fat mobilization on early lactating cows grazing at low HA.

The energy intake and cow performances were greatly reduced on the SG10 treatment. Cow performances increased up to an herbage allowance of $30 \mathrm{~kg} \mathrm{DM} / \mathrm{cow} / \mathrm{d}$ but considering the decrease of the stocking density (117 and 83 cow/ha respectively for SG20 and SG30) and milk output per ha, the optimum allowance appears to be about 20 and $25 \mathrm{~kg} \mathrm{DM} / \mathrm{cow} / \mathrm{d}$.

\begin{tabular}{|c|c|c|c|c|c|c|c|c|c|}
\hline & \multicolumn{3}{|c|}{ Treatments } & \multicolumn{2}{|c|}{$\begin{array}{l}\text { Stage of } \\
\text { lactation }\end{array}$} & \multirow[b]{2}{*}{$\operatorname{Lin}$} & \multirow[b]{2}{*}{ Quad } & \multirow[b]{2}{*}{ SGXSL } & \multirow[b]{2}{*}{ rsd } \\
\hline & SG10 & SG20 & SG30 & SL1 & SL2 & & & & \\
\hline milk production $(\mathrm{kg} / \mathrm{d})$ & 14.0 & 17.0 & 19.2 & 20.3 & 13.1 & $<0.01$ & 0.20 & 0.19 & 1.03 \\
\hline milk fat content $(\mathrm{g} / \mathrm{kg})$ & 42.0 & 38.5 & 37.3 & 36.5 & 42.1 & $<0.01$ & 0.28 & $<0.01$ & 3.52 \\
\hline milk protein content $(\mathrm{g} / \mathrm{kg})$ & 28.4 & 28.6 & 29.1 & 26.9 & 30.5 & 0.49 & 0.84 & 0.19 & 2.78 \\
\hline C18 : 1 (\% milk fatty acids) & 31.3 & 27.4 & 26.6 & 29.1 & 27.8 & $<0.01$ & $<0.01$ & $<0.01$ & 0.95 \\
\hline herbage intake $(\mathrm{kgDM} / \mathrm{d})$ & 9.0 & 15.9 & 19.5 & nd & nd & $<0.01$ & 0.10 & nd & 0.97 \\
\hline
\end{tabular}

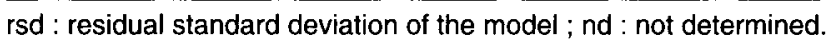

